\title{
USING PSEUDOMONAS FLUORESCENS AS MICROBIAL BIOCONTROL AGENT AGAINST THE SPIDER MITE, TETRANYCHUS CUCURBITACEARUM (SAYED)(ACARI: TETRANYCHIDAE)
}

\author{
WAKED, DALIA A. ${ }^{1}$, M. ELEAWA ${ }^{1}$ and A. SALAMA ${ }^{2}$ \\ 1. Plant Protection Research Institute, ARC, Dokki, Giza, Egypt \\ 2. Agric. Microbiol. Dept., Fac. Agric., Zagazig Univ., Egypt
}

(Manuscript received 17 May 2016)

\begin{abstract}
$\mathrm{T}$ his study investigated Pseudomonas fluorescens as a potential biological control agent of Tetranychus cucurbitacearum by using two different methods; spraying and dipping. The earliest death occurred within the first day after the treatments. The highest mortality (100\%) and the lowest $68.75 \%$ for the spraying bacterial treatment and $58.75 \%$ and $16.25 \%$ for the dipping. The longevity was shorter than control in both methods. Female longevity averaged 10.32 and 17.04 days for the spraying and the dipping while, 22.5 and 24.19 days in control. The bacterial treatment reduced the total deposited eggs in females to half approximately in the spraying method while, in the dipping method was nearly with the control. The chitinase enzyme present in the cell was confirmed by the positive result of chitin clearing zone.
\end{abstract}

Keywords: Pseudomonas fluorescens, Tetranychus cucurbitacearum, biological control, chitinase

\section{INTRODUCTION}

In Egypt, field and vegetables crops are considered of great economic important for local consumption and exportation. Plant parasitic mites tend to be serious agriculture pests worldwide Zaher (1986). Mites especially family tetranychidae are common pests in agriculture system causing in many cases greater economic losses than any other arthropods pests. Tetranychus cucurbitacearum (Sayed) is considered one of the major pests attacking different crops; field, vegetables, fruits and ornamental plants (Taha et al. 2001 and Magouz and Saadoon 2005). Chemical control is a commonly used management tactic against T.cucurbitacearum in several crops in Egypt. The intensive use of pesticides has caused a considerable reduction of its efficacy due to the evaluation of resistance that indicates a need to develop alternative integrate pest management strategies for suppressing its population Amin et al. (2009). One of the alternative managements is using Pseudomonas fluorescens as microbial biocontrol agent. Pseudomonas putida as a potential biological control agent of Tetranychus urticae. Bacterial application significantly reduced total egg numbers and egg hatching, compared to their 
respective controls. Bacterial spraying was significantly more effective than dipping the spray application demonstrated 100\% efficacy Aksoy et al. (2008). Bacterial chitinases have been reported to be effective in controlling the insects and mites by hydrolyzing chitinous exoskeleton Kramer and Muthukrishnan, (1997). Highest rate of reduction and effectiveness on spider mite $100 \%$ mortality was achieved after four days by using high concentration of $P$. fluorescens Al-Sohim and Fouly (2015).

\section{MATERIALS AND METHODS}

\section{Isolation of Pseudomonas}

The $10 \mathrm{~cm}$ rhizhosphere soil particles loosely adhering to the roots were gently teased out and the roots were cut into small pieces and mixed well. The soil thus obtained was shaken with $90 \mathrm{ml}$ of sterile distilled water for 10-20 min. to obtain standard soil suspension. Isolation of Pseudomonas was made by following the serial dilutions and pour plate method using the specific King's B medium King et al.(1954). One $\mathrm{ml}$ of soil suspension from aliquot dilutions was aseptically added to sterile Petri plates containing twenty $\mathrm{ml}$ of sterile medium and incubated at $28 \pm 2{ }^{\circ} \mathrm{C}$ for $48 \mathrm{~h}$. After incubation, well separated individual colonies with yellow green and blue white pigments were marked and detected by viewing under UV light. The individual colonies were picked up with sterile loop and transferred to fresh King's B slants and the pure cultures so obtained were stored in refrigerator at $4^{\circ} \mathrm{C}$ for further use. Morphological characterization of pure cultures of the selected isolates was streaked on King's B agar Petri plates separately for colony development. The individual colonies were examined for shape, size, structure of colonies and pigmentation.

\section{Morphological and Biochemical characteristics of the isolated bacteria}

The direct microscopic examination of stained smears of bacterial isolates was carried out for studying shape of the bacterial cells, gram staining, spore staining and motility. Biochemical testes of these cultures were also examined according to the key of Bergey's Manual of Systematic Bacteriology (Krieg and Holt 1984 and Sneath et al. 1986).

\section{Stock culture of spider mite, Tetranychus cucurbitacearum}

Population of T.cucurbitacearum collected from Cucumber plant (Cucumissativus) zagazig district. Samples that contained the mites were transferred immediately to the laboratory used as stock culture. From the stock adults and immature stages were transferred onto fresh mulberry leaves (Morusalba L.) placed on moistened cotton pads in plastic trays. Rearing trays were kept under controlled conditions of $27 \pm 2{ }^{\circ} \mathrm{Cand} 65 \pm 5 \mathrm{R} . \mathrm{H}$. Withered and dry leaves were regularly replaced. 


\section{Bioassay}

The effect of $P$. fluorescens was evaluated against adults of spider mite adopting two different methods, spraying and dipping methods of bacterial suspension at the concentrations of 100,75 and $50 \%$. Spray method was applied with Eighty adult females of T.cucurbitacearum transferred means of camel- $\mathrm{s}$ hair brush bio-assayed in 8 replicates of 10 adult females each to mulberry leaf discs each about $1.5 \mathrm{~cm}$ diameter were gently sprayed separately in serial concentrations of $P$. fluorescens and putted in petri-dishes, $10 \mathrm{~cm}$. diameters. Dipping method was bio-assayed with the same number of adult females of T.cucurbitacearum from the above method. Mulberry leaves were dipped in each concentration for 10 seconds then left to dry that putted in petri-dishes that adult females of T.cucurbitacearum were transferred. Bioassay included untreated check in which leaves were sprayed and dipped in water only. All petri-dishes were held at the same conditions of $27 \pm 2{ }^{\circ} \mathrm{C}$ and $65 \pm 5$ R.H. All mites responded to touching with camel's hair brush was considered alive one percentages of accumulated mortality was collected according to Abbott's formula.

\section{Latent effect of $\mathrm{LC}_{50}$ of $\boldsymbol{P}$. fluorescenson some biological aspects of spider mite, T. cucurbitacearum}

Eight adult individuals of T.cucurbitacearum were transferred to mulberry leaf discs about $2 \mathrm{~cm}$. diameter each replicate 10 times. The spray and dipping methods was applied as mention above. The alive individuals were observed then the longevity and fecundity in addition to egg hatching of T.cucurbitacearum females and deterrent index \%were calculated. Deterrent index \% based on the number of eggs on control and tested leaf discs Lundgren (1975)formula as follow:

Deterrent index $\%=\frac{B-A}{B+A} \times 100$

A: Number of eggs in treatment, B: Number of eggs in control.

\section{Statistical analysis}

Data were subjected to statistical analysis using one way analysis of variance, ANOVA Duncan (1955). 


\section{RESULTS AND DISCUSSION}

\section{The toxicity of Pseudomonas fluorescens on spider mite, Tetranychus cucurbitacearum}

The susceptibility of the mite females of $T$. cucurbitacearum to $P$. fluorescens was evaluated by using two different methods; spraying and dipping. The earliest deaths occurred within the first day after the treatments. All the mites in the spraying bacterial treatment died within 48 hours, so statistical analysis for mortality and efficacy were done using the data on all days. There were highly significant differences in adult mortality among the treatments Table (1). The highest mortality $(100 \%)$ and the lowest $68.75 \%$ for the spraying bacterial treatment and $58.75 \%$ and $16.25 \%$ for the dipping. Bacterial dipping caused mite mortality, significantly lower than the effect of bacterial spraying. The results of this study revealed the potential of $P$. fluorescens as a microbial biocontrol agent by causing significant mortality of $T$. cucurbitacearum. These results agree with (De Flaun et al., 1994 and Mastropaolo et al. 2012) revealed that bacterial mortality may be one of the key elements regarding mite killing as acaricidal function. Al-Sohim and Fouly (2015) indicated that Pseudomonas fluorescens caused higher mortality reached $74.84 \%$ against mite, Oligonychus afrasiaticus.

Table 1. Effect of Pseudomonas fluorescens culture on spider mite, Tetranychus cucurbitacearum (Sayed)

\begin{tabular}{|c|c|c|c|c|c|}
\hline \multirow{2}{*}{ Treatments technique } & \multicolumn{4}{|c|}{$\%$ Mortality after } \\
\cline { 2 - 6 } & & $24 \mathrm{~h}$. & $48 \mathrm{~h}$. & $72 \mathrm{~h}$. & $96 \mathrm{~h}$. \\
\hline \multirow{2}{*}{$100 \%$} & Spraying & $96.25 \pm 3.12^{\mathrm{a}}$ & $100^{\mathrm{a}}$ & $100^{\mathrm{a}}$ & $100^{\mathrm{a}}$ \\
\cline { 2 - 6 } & dipping & $55.00 \pm 2.16^{\mathrm{b}}$ & $55.00 \pm 2.64^{\mathrm{b}}$ & $58.75 \pm 3.01^{\mathrm{b}}$ & $58.75 \pm 3.52^{\mathrm{b}}$ \\
\hline \multirow{2}{*}{$75 \%$} & Spraying & $78.75 \pm 2.73^{\mathrm{b}}$ & $85.00 \pm 2.35^{\mathrm{b}}$ & $88.75 \pm 2.89^{\mathrm{b}}$ & $93.75 \pm 3.17^{\mathrm{b}}$ \\
\cline { 2 - 6 } & dipping & $33.75 \pm 2.34^{\mathrm{b}}$ & $37.5 \pm 1.80^{\mathrm{c}}$ & $38.75 \pm 1.87^{\mathrm{c}}$ & $38.75 \pm 2.65^{\mathrm{c}}$ \\
\hline \multirow{2}{*}{$50 \%$} & Spraying & $68.75 \pm 1.98^{\mathrm{c}}$ & $71.25 \pm 1.92^{\mathrm{c}}$ & $76.25 \pm 1.76^{\mathrm{c}}$ & $78.75 \pm 2.35^{\mathrm{c}}$ \\
\cline { 2 - 6 } & dipping & $16.25 \pm 1.85^{\mathrm{d}}$ & $16.25 \pm 1.78^{\mathrm{d}}$ & $25.00 \pm 1.09^{\mathrm{d}}$ & $27.50 \pm 1.89^{\mathrm{d}}$ \\
\hline \multirow{2}{*}{ Control } & Spraying & $5.00 \pm 0.65^{\mathrm{e}}$ & $6.25 \pm 0.97^{\mathrm{e}}$ & $6.25 \pm 0.64^{\mathrm{e}}$ & $6.25 \pm 0.34^{\mathrm{e}}$ \\
\cline { 2 - 6 } & dipping & $2.5 \pm 0.11^{\mathrm{e}}$ & $2.5 \pm 0.41^{\mathrm{e}}$ & $2.5 \pm 0.21^{\mathrm{e}}$ & $2.5 \pm 0.45^{\mathrm{e}}$ \\
\hline
\end{tabular}

Means in columns followed by the same letter are not significantly different at $5 \%$ level (Duncan'smultiple range tests). $\quad \pm$ Standard Error

The effect of P.fluorescenson the biology of spider mite, T. cucurbitacearum Statistical analysis in Table (2) cleared that $T$. cucurbitacearum longevity affected significantly in both methods of P.fluorescens treatment. The longevity was shorter than control in both methods. Female longevity averaged 10.32 and 17.04 days for the spraying and the dipping while, 22.5 and 24.19 days in control. The bacterial treatment reduced the total deposited eggs in females to half approximately in the spraying method while, in the dipping method was nearly with the control. Almost all eggs hatched in the two controls, but egg hatching was reduced to $48.34 \%$ and $73.12 \%$ in the spraying and the dipping methods. P.fluorescens showed efficacy for 
reduced total deposited eggs with deterrent index $49.24 \%$ and $13.25 \%$ for the spraying and the dipping methods. Aksoy et al. (2008) investigated that Pseudomonas putidabio type $\mathrm{B}$ as a potential biological control agent of Tetranychus urticaethat reduced total egg numbers and egg hatching.

Table 2. Latent effect withL $\mathrm{C}_{50}$ of Pseudomonas fluorescens on some biological aspects of Tetranychus cucurbitacearum

\begin{tabular}{|c|c|c|c|c|}
\hline $\begin{array}{c}\text { Methods of } \\
\text { treatment }\end{array}$ & $\begin{array}{c}\text { Longevity (in } \\
\text { days) }\end{array}$ & $\begin{array}{c}\text { Total } \\
\text { eggs/female }\end{array}$ & Egg hatching \% & Deterrent index \% \\
\hline Spraying & $10.32 \pm 1.14^{\mathrm{c}}$ & $23.13 \pm 1.16^{\mathrm{c}}$ & $48.34 \pm 3.26^{\mathrm{c}}$ & 49.24 \\
\hline Control & $22.5 \pm 1.95^{\mathrm{a}}$ & $68.01 \pm 5.2^{\mathrm{a}}$ & $95.57 \pm 5.73^{\mathrm{a}}$ & - \\
\hline Dipping & $17.04 \pm 1.18^{\mathrm{b}}$ & $54.18 \pm 3.25^{\mathrm{b}}$ & $73.12 \pm 3.22^{\mathrm{b}}$ & -25 \\
\hline Control & $24.19 \pm 2.02^{\mathrm{a}}$ & $70.63 \pm 5.36^{\mathrm{a}}$ & $95.23 \pm 4.54^{\mathrm{a}}$ & - \\
\hline
\end{tabular}

Means in columns followed by the same letter are not significantly different at5\% level (Duncan's multiple range tests). \pm Standard Error

\section{Enzyme assay}

The mortality due to affected with P.fluorescens due to the chitinase enzyme present in the cell which was confirmed by the positive result of chitin clearing zone study. Fig. (1). Bacterial chitinases have been reported to be effective in controlling the insects and mites by hydrolyzing chitinous exoskeleton Kramer and Muthukrishnan (1997).

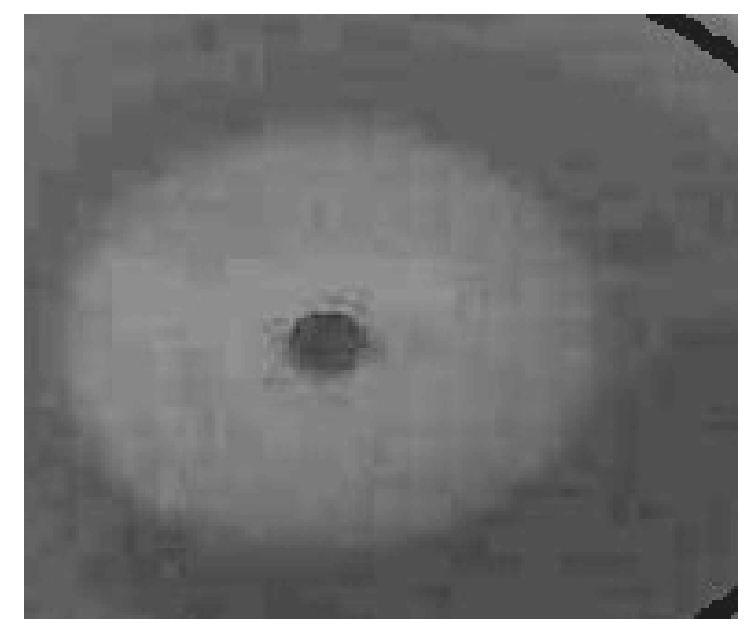

Fig. 1. Chitin clearing zone of P.fluorescens effect.

\section{REFERENCES}

1. Aksoy H. M.; S. K. Ozman-Sullivan; H. Ocal; N.Celik and G. T. Sullivan 2008. The effects of Pseudomonas putida biotype Bon Tetranychusurticae (Acari: Tetranychidae). J. Expe. Appl.Acarol. 46 (1-4): 223-230. 
2. Al-Sohim, A. S. and A. F. Fouly 2015. Biological effects of two bacterial isolates and mutants of Pseudomonas fluorescens on date palm red spider mite, Oligonychus afrasiaticus (Acari: Tetranychidae). Egyptian, J. Biological Pest Control. 25(2):513-518.

3. Amin, M. M.; R. F. Mizell and R. W. Flowers. 2009. Response of the predatory mite, Phytoseiulus kairomones of three spider mite species (Acari: Tetranchidae) and non-prey food. Florida. Entomologist. 29 (4): 554-562.

4. DeFlaun, M. F.; B. M. Marshall;E. P. Kulleand S. B. Levy. 1994. Tn5 insertion mutants of Pseudomonas fluorescens defective in adhesion to soil and seeds. Appl. Environ. Microbiol., 2637-2642

5. Duncan, D. B. 1955. Multiple range and multiple F. tests. Biometrics. 11:1-41

6. King, E. D.; M. K. Ward and D. E. Raney. 1954. Two simple media for the demonstration of pyocyanin and fluorescin. J. Lab. Clin. Med. 44:301-307

7. Kramer K. J. and S. Muthukrishnan. 1997. Insect chitinases: molecular biology and potential use as biopesticides. Insect Biochem Mol., 27: 887-900

8. Krieg, N. R. and J. G. Holt. 1984. Bergy's manual of determinative bacteriology, volume 1.Baltimore, Williams and Wilkins Co.

9. Lundgren, L. 1975. Natural plant chemicals acting as oviposition deterrents on cabbage butterflies, Pierisbrassicae (L.), P. rapa (L.) and P. napi (L.). Zoll. Ser., 4: $250-258$.

10. Magouz, R. I. E. and Saadoon, Sohair E. 2005. Effect of some environmentally save compounds on Tetranychus cucurbitacearum (Sayed) under laboratory and field conditions. J. Agric. Res. Tanta Univ., 31(2):293-304.

11. Mastropaolo, M. D.; M. W. Silby; J. S. Nicoll and S. B. Levy. 2012. Novel genes involved in Pseudomonas fluorescens pf0-1 mortality and biofilm formation. Appl. Environ. Microbiol., 78: 4318-4329.

12. Sneath, P. H. A.; N. S. Mair; M. E. Sharpe and J. G. Holt. 1986. Bergey's manual of systematic bacteriology, vol.2.Baltimore:Williams\&Wilkins

13. Taha, H. A.; Shoeib, Amira A.; Younes, Ahlam A. and M. A. Ahmed. 2001. Susceptibility of ten soybean varieties to some sucking pests with respect to certain climatic factors infectiveness. J. Agric. Sci. Mansoura Univ., 26(8):50595066.

14. Zaher, M. A. 1986. Predaceous and non-predaceous mites in Egypt (Nile Valley and Delta).PL. 480 Prog.USA Project No. EGARS-30, Grant No.FG-EG-139. 
إستخلام بكتيريا Pseudomonas fluorescens كعامل مكافحة ميكروبية حيوية ضد العنكبوت الأحمر

Tetranychus cucurbitacearum (Sayed)(Acari:Tetranychidae)

$$
\begin{aligned}
& \text { داليا عبدالرحمن أحمد واكد' ومحمد عليوه محمد' وعلى سلامه' } \\
& \text { ا ـ ـعهد بحوث وقاية النباتات - مركز البحوث الزراعية- الدقى- الجيزه- دصر }
\end{aligned}
$$

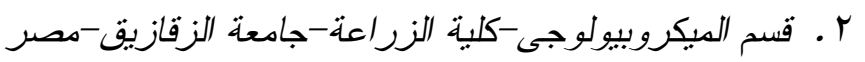

أثتتت هذه الدراسة فعالية بكتيريا Pseudomonas fluorescens كأحد عوامل المكافحة

الميكروبية للحلم العنكبوتى Tetranychus cucurbitacearum حيث أُستخدم فى هذه الدراسة طريقتن للمعاملة وهما طريقة الرش وطريقة غمر الورقة. - أظهرت النتائج المتحصل عليها إلى حدوث نسبة موت في إناث الحلم المعامل بهذه البكتيريا وذلك

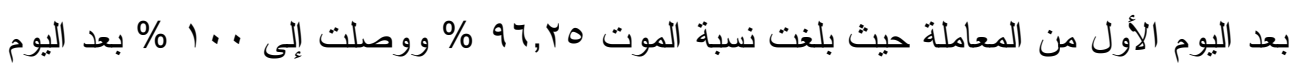

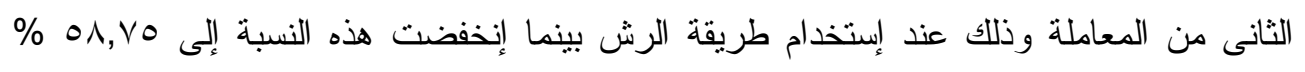

$$
\text { عند إستخدام طريقة الغمر للورقة. }
$$

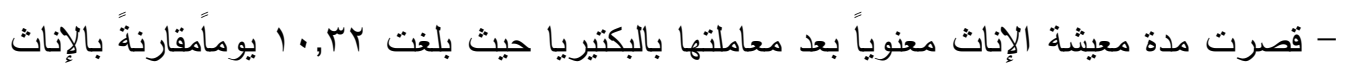

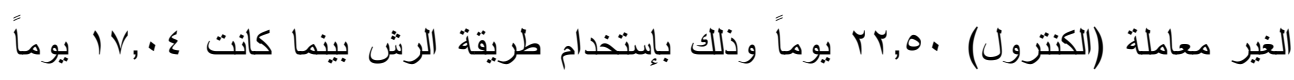

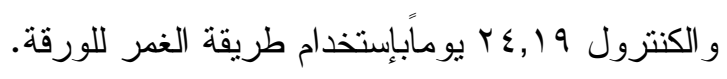

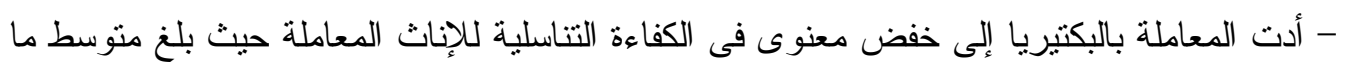

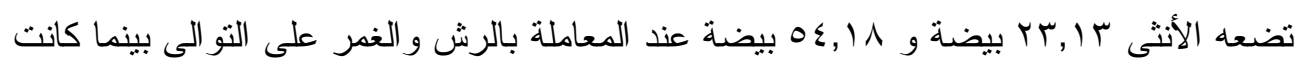

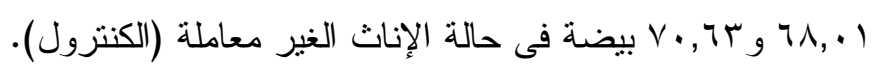

